\title{
FATTY ACID COMPOSITION OF DRINKING COW'S MILK TRADE NETWORKS OF KYIV
}

\author{
Vyacheslav DANCHUK, Svitlana MIDYK, Valerii USHKALOV, Olga IAKUBCHAK, Ihor HRYSHCHUK, Liliana \\ DAVYDOVSKA
}

National University of Life and Environmental Sciences of Ukraine

Corresponding author: Svitlana Midyk, e-mail: svit.mid@gmail.com

DOI: $10.38045 /$ ohrm.2022.1.05

CZU: 637.12.04/.07:339.378(477-25)

Keywords: fatty acids, drinking cow's milk.

Cuvinte cheie: acizi grași, lapte de vacă.
Introduction. There are several important aspects requiring a control of fatty acid composition in drinking milk distributed across the retail stores: milk is one of the main consumer products; fatty acids are the main energy substrates, involved in the synthesis of cellular structural components, whereas their interaction might impact the intensity of body growth and development; the fatty acid composition of milk varies depending on the diet and the animal's specific physiological state; in case of udder diseases, a change milk composition may occur; prevention of product counterfeiting distributed across the retail stores.

Material and methods. The present research examined milk samples from five dairy producers that distribute their products across the retailing chains in Kyiv. Milk samples were collected to determine the fatty acid composition. Milk fat was extracted following the Folch method. The milk fatty acid content assessment was carried out by gas chromatography.

Results. 20 fatty acids were identified in the tested milk samples. A higher level of saturated fatty acids was recorded in milk from "Ferma" and "Selyanskoye for kids" dairy producers. The highest content of unsaturated fatty acids was registered in products of "Ukrainskoe" and "Molokia" dairy trademarks.

Conclusions. The fatty acid composition of the drinking cow's milk distributed across trading networks in Kiev was found to be heterogeneous, by differing in the content of both long-chain saturated fatty acids and unsaturated fatty acids.

\section{COMPOZIȚIA ACIZILOR GRAȘI ÎN LAPTELE DE VACĂ DE BĂUT DIN RETELELE COMER- CIALE DIN OR. KIEV, UCRAINA}

Introducere. Există câteva aspecte importante care necesită un control riguros al compoziției acizilor grași din laptele de băut distribuit în magazinele de vânzare cu amănuntul: laptele este unul dintre produsele esențiale de consum; acizii grași sunt principalele substraturi energetice implicate în sinteza componentelor structurale celulare, în timp ce interacțiunea lor ar putea afecta intensitatea dezvoltării organismului uman; compoziția acizilor grași din lapte variază în funcție de alimentație și de starea fiziologică specifică animalului; în cazul bolilor ugerului poate surveni modificarea compoziției laptelui; prevenirea contrafacerii produselor lactate distribuite în magazinele de vânzare cu amănuntul.

Material si metode. Prin prezenta cercetare s-au examinat mostrele de lapte de la cinci producători de lactate care își distribuie produsele prin lanțurile de vânzare cu amănuntul din or. Kiev pentru a determina compoziția acizilor grași. Grăsimea din lapte a fost extrasă prin metoda Folch. Evaluarea conținutului de acizi grași din lapte a fost efectuată prin cromatografie gazoasă.

Rezultate. În probele de lapte testate au fost identificați 20 de acizi grași. Un nivel mai ridicat de acizi grași saturați a fost înregistrat în laptele de la producătorii de lactate „Ferma” și „Selyanskoye pentru copii”. Cel mai mare conținut de acizi grași nesaturați a fost înregistrat în produsele mărcilor comerciale de lactate „Ukrainskoe” și „Molokia”.

Concluzii. Compoziția de acizi grași din laptele de vacă distribuit în rețelele comerciale din or. Kiev s-a dovedit a fi heterogenă, prin diferența în conținutul atât de acizi grași saturați cu lanț lung, cât și de acizi grași nesaturați. 


\section{INTRODUCTION}

The nutritional value of drinking cow's milk distributed by trade networks across different countries worldwide may slightly differ, regardless of the technological performance for obtaining raw milk. Certainly, the milk composition is genetically determined and varies among different species of mammals, however, significant fluctuations may also occur in the indices of drinking milk composition within the same species. If considering the lipid composition of drinking milk and disregarding the impact of pathological factors (such milk is not used), as well as product counterfeiting, then, the following should be mentioned: breed and physiological characteristics of the lactating animals; the diet composition; technologies for keeping dairy cows (grazing on pastures, exercise, transportation, etc.); technologies for obtaining drinking milk. Some researchers believe that the behaviour, exercise, and grazing intensity and duration of lactating animals can also affect the composition and quality of the milk obtained $(1,2)$.

As regarding certain interspecies characteristics, then eleven branched-chain fatty acids have been identified in camel milk, which are preferably C15:0, anteiso-C15:0 and C17:0 anteiso-C17:0 (3).

Cow milk lipids consist mainly of triglycerol (98\%), diacylglycerol (2\%), non-esterified and esterified cholesterol $(<0.5 \%)$, phospholipids $(1 \%)$ and free fatty acids $(0.1 \%)(4)$.

A number of studies described that the digestive system of ruminants has a great impact on the quality and chemical composition of milk, as well as its suitability for cheese production. Cow's milk has a higher level of monounsaturated fatty acids and a lower $n 6 / \mathrm{n} 3$ ratio compared to sheep and goat's milk, which show a higher amount of polyunsaturated $n 3$ fatty acids $(5,6,7)$.

The milk of each dairy animal species has its own specific lipid profile used in formulating of the dairy products to obtain the intended technological and nutritional parameters. Stable milk quality and safety indices are of great importance for the food processing industry. Free fatty acids, especially the short-chain ones, show a lower taste threshold, providing characteristic organoleptic characteristics properties of fermented dairy products, particularly in cottage cheese $(8,9)$.
Free fatty acids also contribute to the raw milk technological suitability for being processed, as they impact on surface tension and foaming ability of the milk (10).

In mammary gland pathologies, including subclinical mastitis, both milk safety indicators and milk fatty acid composition may alter (11).

Drinking milk 1-2 times a month was associated with lower all-cause mortality in men compared with those who never drank milk (12). When buying milk for children, a person hopes to get a product characterized by a particular content of essential fatty acids and readily available energy, which would meet a growing body's needs, both in the structural lipid synthesis and biologically active substances, and in providing sufficient amount of ATP energy for children's growth and development (13).

The 1994 EU Council Regulation 1234/2007 and the EU Commission Regulation No 445/2007 set standards for fatty oils, including functional fats and spreads. They defined fats into different categories, such as butter, margarine and blend spreads. Spreadable fats undergo standard classification according to their fat content and whether they are dairy/non-dairy, vegetable/animal origin) (14).

Ukraine is actively implementing regulations on specific indicators providing quality and safety of food products, particularly in milk, according to the requirements of the EU. Modern requirements for raw milk involve careful analysis (15).

The following major aspects have drawn our attention to the need of monitoring the fatty acid composition of drinking milk distributed across the retail chains: milk is one of the main consumer products used by a significant category of population and its quality impacts food security within the state; fatty acids are the main energy substrate and the source of the structural lipids synthesis; milk lipids exhibit a high metabolic activity; raw milk fatty acid composition can vary depending on the animal's diet and specific physiological state; prevention of product counterfeiting.

The purpose of this study was to investigate the nutritional value of the lipid component of drinking milk distributed across the retail chains in Kyiv. 


\section{MATERIAL AND METHODS}

The pasteurized cow milk from five manufacturers was studied, the dairy products found in retail stores across Kyiv (Ferma, Ukrainskoe, Molokia, Zlagoda and Selyanskoe for kids). Milk samples were studied to determine the fatty acid composition.

The extraction of total lipids was performed using Folch method (16). Next, the sample preparation was carried out by hydrolysis and methylation of fatty acids. Therefore, $4 \mathrm{~cm}^{3}$ of methyl sodium hydroxide solution was added to $100 \mathrm{mg}$ of the obtained fat, then a reflux condenser was attached to the flask and boiled until the fat droplets disappeared, by stirring the flask content with 30-60 second intervals. $5 \mathrm{~cm}^{3}$ of a methyl boron trifluoride solution was added to the flask content and boiling for up to 1 hour. $3 \mathrm{~cm}^{3}$ hexane was added to the boiling mixture through the top of the reflux condenser and then removed from the heating element. $20 \mathrm{~cm}^{3}$ of saturated sodium chloride solution was added to the hot mixture and stirred for 15 seconds. The upper (hexane) layer was collected for research in accordance with the current DSTU ISO standards (17). The analysis of fatty acids methyl esters was carried out via a Trace GC Ultra gas chromatograph (United States) with a flame ionization detector. The following chromatograph operating conditions were considered: column temperature was maintained at $140-240^{\circ} \mathrm{C}$ and detector temperature - at $260^{\circ} \mathrm{C}$. A TriPlus autosampler at a dose of $1 \mu \mathrm{L}$ was used to inject the sample into the chromatograph. The analysis duration was 65 min. Fatty acids were identified using a standard Supelco 37 Component FAME Mix sample. The quantitative spectral assessment of milk fatty acids was carried out by internal normalization and by determining their percentage content. Three parallel studies were carried out.

The statistical processing of the experimental data was carried out using the generally accepted methods. The Student's $t$-test was used for assessing the statistical significance of indicators. Differences between the compared indicators were considered reliable at a significance level of $\mathrm{P} \leq 0.05, \mathrm{P} \leq 0.01$.

\section{RESULTS}

As it has already been mentioned above, the fatty acid composition of consuming milk, distributed across the retail chains, depends on many factors associated with both the quality of raw material supplied to the dairy processing plants and the depth of processing, namely, the technologies used by different dairy manufacturers. Therefore, the fatty acid composition of consuming milk collected from different manufacturers in Ukraine somewhat varies (tab. 1). The milk fat of all the selected milk samples collected from various trademarks included 20 fatty acids, such as: C4:0, C6:0, C8:0, C10:0, C11:0, C12:0, C14:0, C14:1, C15:0, C16:0, C16:1n9c, C17:0, C17:1, C18:1n9c, C18:2n6c, C18:3n3, C21:0, C22:0, C20:3n6.

It should be noted that the studied samples met the microbiological safety criteria (lack of Salmonella spp., Listeria monocytogenes, Staphylococcus aureus, coliforms) and quality standards (the number of mesophilic aerobic and facultative anaerobic microorganisms) established for milk.

Following the laboratory findings, the fatty acid composition of Ferma dairy brand $(2.5 \%$ fat content) contained the highest amount of fatty acids with a chain length from $\mathrm{C} 4: 0$ to $\mathrm{C} 16: 0$ (59.33\%) as related to the lowest fatty acids content ranging from C17:0 to C22:0, compared with the relative content of the corresponding fatty acids in selected milk samples of other dairy brands. It should be noted that the percentage of only the following saturated fatty acids C4:0, C16:0, and C18:0 showed a significant difference $(\mathrm{p}<0.05-$ $\mathrm{p}<0.01$ ) in the tested samples, whereas in all other cases we can only discuss about trends. This dairy brand also showed the lowest content of unsaturated fatty acids (fig. 1) (26.21\%), as it decreased mainly due to $\mathrm{C} 18: 1 \mathrm{n} 9 \mathrm{c}$ and $\mathrm{C} 18: 2 \mathrm{n} 6 \mathrm{c}$ $(\mathrm{p}<0.05)$.

As regarding "Ukrainskoe" dairy brand (2.5\% fat), it showed almost similar values to the samples of "Molokiya" (1.6\% fat) and "Zlagoda" (3.2\% fat) dairy brands in terms of the relative content of saturated fatty acids, the indicators ranging between $69.75 \%-72.89 \%$ (fig. 1). While the content of the total amount of saturated fatty acids in the "Selyanskoye for kids" dairy brand (2.5\% fat), in terms of its indicators, was closer to the values found in milk samples of "Ferma" dairy brand. The content of unsaturated fatty acids in dairy samples of various brands increased as following: $26.19 \%$ ("Ferma") <26.49\% ("Selyanskoe for kids") $\quad<27.11 \% \quad$ ("Zlagoda") $<29.99$ ("Ukrainskoe") <30.25\% ("Molokiya"). 
Table 1. Fatty acid composition of pasteurized cow's milk ( $\mathrm{M} \pm \mathrm{m}, \%, \mathrm{n}=5)$.

\begin{tabular}{|c|c|c|c|c|c|}
\hline Fatty acids & $\begin{array}{l}\text { "Ferma", } \\
2.5 \% \text { fat }\end{array}$ & $\begin{array}{c}\text { "Ukrainskoe", } \\
2.5 \% \text { fat }\end{array}$ & $\begin{array}{l}\text { "Molokia", } \\
1.6 \% \text { fat }\end{array}$ & $\begin{array}{l}\text { "Zlagoda", } \\
3.2 \% \text { fat }\end{array}$ & $\begin{array}{c}\text { "Selyanskoe } \\
\text { for kids", } \\
2.5 \% \text { fat }\end{array}$ \\
\hline C4:0 & $3.91 \pm 0.23$ & $3.41 \pm 0.37$ & $3.26 \pm 0.16^{*}$ & $2.97 \pm 0.24^{*}$ & $3.76 \pm 0.12$ \\
\hline C6:0 & $2.79 \pm 0.13$ & $2.43 \pm 0.25$ & $2.41 \pm 0.31$ & $2.40 \pm 0.11^{*}$ & $2.51 \pm 0.32$ \\
\hline C8:0 & $1.75 \pm 0.26$ & $1.52 \pm 0.23$ & $1.47 \pm 0.20$ & $1.51 \pm 0.21$ & $1.55 \pm 0.2$ \\
\hline C10:0 & $3.77 \pm 0.19$ & $3.35 \pm 0.25$ & $3.12 \pm 0.15^{*}$ & $3.22 \pm 0.16$ & $3.30 \pm 0.22$ \\
\hline C11:0 & $0.42 \pm 0.09$ & $0.35 \pm 0.05$ & $0.32 \pm 0.03$ & $0.33 \pm 0.02$ & $0.34 \pm 0.03$ \\
\hline C12:0 & $4.11 \pm 0.21$ & $3.76 \pm 0.39$ & $3.50 \pm 0.17^{*}$ & $3.58 \pm 0.28$ & $3.90 \pm 0.19$ \\
\hline C14:0 & $12.12 \pm 0.30$ & $11.48 \pm 0.31$ & $10.96 \pm 0.36^{*}$ & $11.65 \pm 0.38$ & $11.85 \pm 0.39$ \\
\hline C14:1 & $1.63 \pm 0.04$ & $1.59 \pm 0.25$ & $1.45 \pm 0.04 *$ & $1.57 \pm 0.15$ & $1.49 \pm 0.16$ \\
\hline C15:0 & $1.52 \pm 0.11$ & $1.31 \pm 0.13$ & $1.22 \pm 0.12$ & $1.36 \pm 0.14$ & $1.37 \pm 0.15$ \\
\hline C16:0 & $32.85 \pm 0.65$ & $29.82 \pm 0.59^{*}$ & $31.08 \pm 1.11$ & $30.76 \pm 0.59 *$ & $32.59 \pm 0.84$ \\
\hline C16:1n9c & $1.95 \pm 0.28$ & $1.96 \pm 0.28$ & $1.82 \pm 0.27$ & $1.91 \pm 0.28$ & $1.83 \pm 0.27$ \\
\hline C17:0 & $0.60 \pm 0.15$ & $0.69 \pm 0.17$ & $0.60 \pm 0.15$ & $0.73 \pm 0.13$ & $0.66 \pm 0.14$ \\
\hline C17:1 & $0.12 \pm 0.03$ & $0.29 \pm 0.05^{*}$ & $0.23 \pm 0.09$ & $0.31 \pm 0.07^{*}$ & $0.15 \pm 0.08$ \\
\hline C18:0 & $9.45 \pm 0.31$ & $10.85 \pm 0.36^{*}$ & $11.02 \pm 0.35^{*}$ & $12.23 \pm 0.46^{* *}$ & $11.00 \pm 0.40^{*}$ \\
\hline C18:1n9c & $18.76 \pm 0.57$ & $20.82 \pm 0.71^{*}$ & $20.85 \pm 0.70^{*}$ & $20.62 \pm 0.75$ & $19.47 \pm 0.68$ \\
\hline C18:2n6c & $3.04 \pm 0.25$ & $4.45 \pm 0.30^{* *}$ & $5.23 \pm 0.35^{* *}$ & $3.09 \pm 0.33$ & $3.11 \pm 0.22$ \\
\hline C18:3n3 & $0.45 \pm 0.13$ & $0.64 \pm 0.16$ & $0.45 \pm 0.13$ & $0.51 \pm 0.14$ & $0.34 \pm 0.11$ \\
\hline C21:0 & $0.53 \pm 0.15$ & $1.02 \pm 0.20$ & $0.66 \pm 0.16$ & $1.05 \pm 0.19$ & $0.46 \pm 0.13$ \\
\hline C22:0 & $0.02 \pm 0.01$ & $0.05 \pm 0.04$ & $0.17 \pm 0.08$ & $0.14 \pm 0.07$ & $0.18 \pm 0.08$ \\
\hline C20:3n6 & $0.26 \pm 0.09$ & $0.26 \pm 0.12$ & $0.26 \pm 0.05$ & $0.11 \pm 0.06$ & $0.13 \pm 0.07$ \\
\hline
\end{tabular}

* $\mathrm{P} \leq 0.05$, ** $\mathrm{P} \leq 0.01$ - as related to data collected from Ferma dairy rademark samples ( $2.5 \%$ fat); these data are presented as mass fraction of fatty acids expressed in $\%$ of the fatty acid amount.

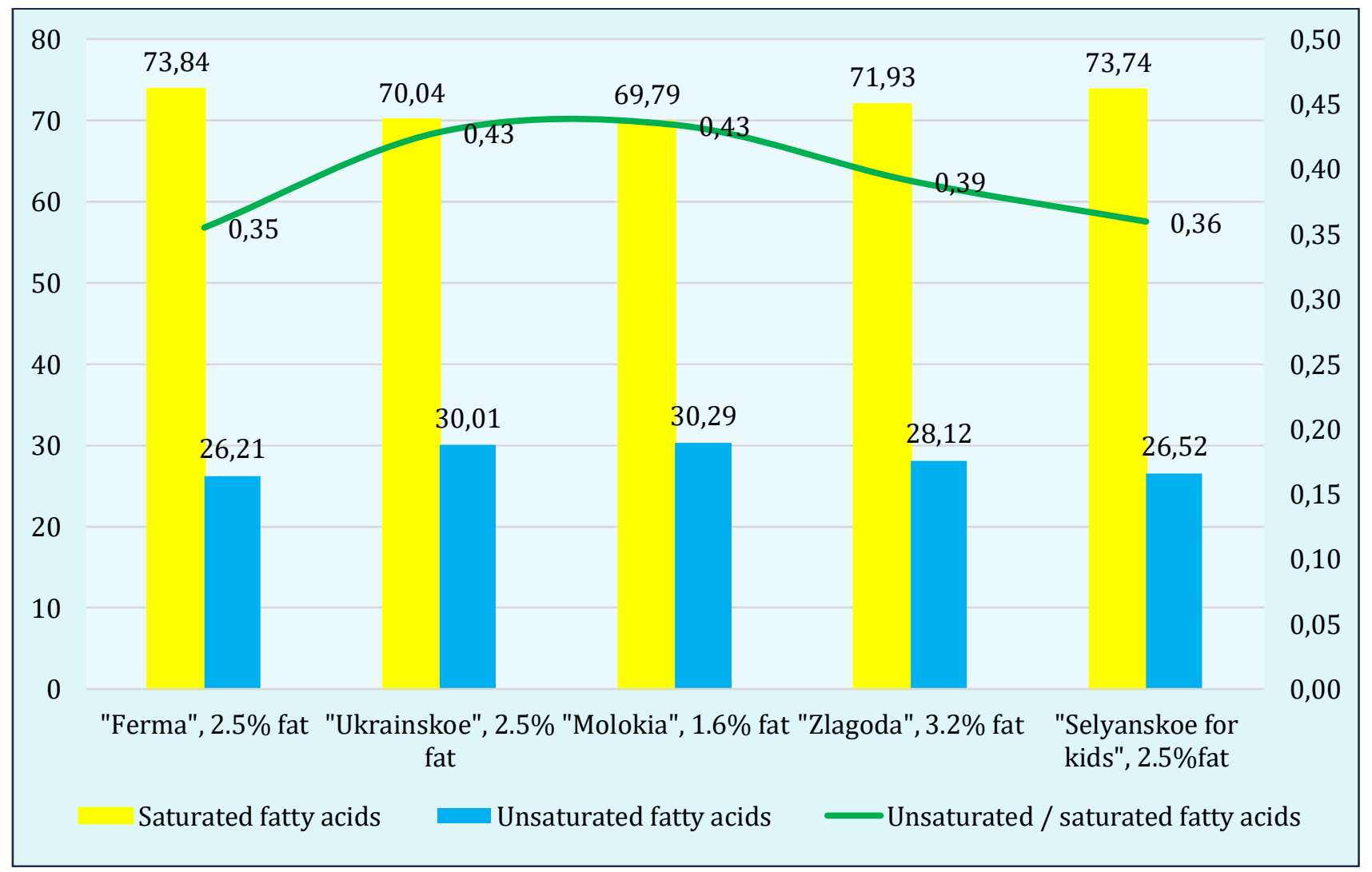

Figure 1. The ratio of the total amount of fatty acids in drinking milk. 
As shown in Figure 1, the "Selyanskoe for kids" dairy brand $(2.5 \%$ fat $)$ exhibited a higher amount of saturated fatty acids. However, the high percentage was not related to chain length of the fatty acids with a from C4:0 to C12:0, as described in the samples of the "Ferma" dairy brand $(2.5 \%$ fat), but rather due to the higher content of C18:0 $(p<0.05)$ and $\mathrm{C16}: 0$ indicators.

\section{DISCUSSIONS}

The present studies have revealed a somewhat wide range of fluctuations in the fatty acid composition of milk collected from different dairy manufacturers. There is no doubt that the fatty acids of raw milk supplied for dairy processing is decisive for the finished product characteristics, however, the impact of the processing depth of raw material on the quality of the final product should also be considered.

Certainly, under conditions when the fatty acid composition of the distributed consuming milk is not normalized, dairy producers are not significantly restricted in manipulating the nutritional value of its lipid component. Surely, there may be an increase in the content of short-chain saturated fatty acids in "Ferma" dairy brand $(2.5 \%$ fat), having a certain dietary value, however, a decrease in the total amount of unsaturated fatty acids indicates a decrease in the nutritional value of the product. On the other hand, a decrease in fat content to $1.6 \%$ in "Molokia" products do not show a negative impact on its fatty acid composition; moreover, the content of unsaturated fatty acids in these samples was the highest, which is definitely a positive factor.

The study results revealed a heterogeneous content of polyunsaturated fatty acids C18:2n6c, C18:3n3 and C20:3n6 in the samples of different studied dairy brands: the lowest content was found in the "Selyanskoe for kids", $2.5 \%$ fat (3.58\%), "Zlagoda", $3.2 \%$ fat (3.71\%) and "Ferma", $2.5 \%$ fat (3.75\%); the highest "Ukrainskoe", 2.5\% fat (5.35\%) and "Molokiya", $1.6 \%$ fat $(5.94 \%)$.

Although the Ukraine's national system does not provide milk quality standards in terms of fatty acid composition, it should be noted that a significant increase/decrease in the content of certain fatty acids was found in milk obtained from cows with subclinical mastitis, thus indicating dairy product counterfeiting. Therefore, here arises the question regarding the amendment of the regulatory documents on controlling and preventing low-quality milk on the domestic market.

\section{CONCLUSIONS}

1. The fatty acid composition of the drinking milk distributed within the trading stores in Kiev is heterogeneous and differs in the content of both low molecular weight and high molecular weight saturated fatty acids and unsaturated fatty acids. The milk samples of the "Ukrainskoe" (2.5\% fat) dairy brand showed almost similar values to the samples of "Molokiya" (1.6\% fat) and "Zlagoda" ( $3.2 \%$ fat) dairy brands, in terms of the relative content of saturated fatty acids, while according to its indicators, the content of the total amount of saturated fatty acids in the "Selyanskoye for kids" dairy brand ( $2.5 \%$ fat) revealed closer values to those found in "Ferma" dairy brand.

\section{CONFLICT OF INTERESTS}

All authors declare no competing interests.

\section{REFERENCES}

1. Atkins NE, Cianchi C, Rutter SM, Williams SJ, Gauld C, Charlton GL, et al. Performance, milk fatty acid composition and behaviour of highyielding Holstein dairy cows given a limited grazing period. Grass and Forage Science. 2020;75(2):181-191. doi:10.1111/gfs.12471

2. Koczura M, Bouchon M, Turille G, De Marchi M, Kreuzer M, Berard J, et al. Consequences of walking or transport by truck on milk yield and quality, as well as blood metabolites, in Holstein, Montbéliarde, and Valdostana dairy cows. Journal

\section{ACKNOWLEDGMENT}

Research was carried out with the financial support of the Ministry of Education and Science of Ukraine.

of dairy science. 2020;103(4):3470-3478. doi:10.3168/jds.2019-17467

3. Chamekh L, Calvo M, Khorchani T, Castro-Gómez P, Hammadi M, Fontecha J, et al. Impact of management system and lactation stage on fatty acid composition of camel milk. Journal of Food Composition and Analysis. 2020;87:103418.

4. Newburg DS, Neubauer SH, Jensen RG. Handbook of milk composition. San Diego: Academic Press. 1995. P. 273-349. 
5. Paszczyk B, Łuczynska J. The Comparison of Fatty Acid Composition and Lipid. Quality Indices in Hard Cow, Sheep, and Goat Cheeses. Foods. 2020;9(1667):2-14. doi:10.3390/foods9111667

6. Ojha S, Argade A, Raje K, Kumar D, Ahlawat SS. Importance of bovine milk in human diet and effect of adulterated milk on human health. Pharma Innov. 2018;7:453-457.

7. Lopez A, Vasconi M, Moretti VM, Bellagamba F. Fatty acid profile in goat milk from high-and lowinput conventional and organic systems. Animals. 2019;9(7):452. doi:10.3390/ani9070452

8. Amores G, Virto M. Total and free fatty acids analysis in milk and dairy fat. Separations. 2019; 6(1):14. doi:10.3390/separations6010014

9. Chávarri F, Bustamante MA, Santisteban A, Virto M, Barron LJR, de Renobales M. Changes in free fatty acids during ripening of Idiazabal cheese manufactured at different times of the year. Journal of Dairy Science. 1999;82(5):885-890. doi:10. 3168/jds.S0022-0302(99)75307-5

10. Kamath S, Wulandewi A, Deeth H. Relationship between surface tension, free fatty acid concentration and foaming properties of milk. Food Research International. 2008;41:623-629. doi:10. 1016/j.foodres.2008.03.014

11. Danchuk V, Ushkalov V, Midyk S, Vygovska L, Danchuk O, Korniyenko V. Milk lipids and subclinical mastitis. Food science and technology. 2021; 15(2):26-41. doi:10.15673/fst.v15i2.2103

Date of receipt of the manuscript: $03 / 11 / 2021$ Date of acceptance for publication: 20/12/2021

Vyacheslav DANCHUK, ORCID ID: 0000-0003-2156-1758 Svitlana MIDYK, ORCID ID: 0000-0002-2682-2884 Valerii USHKALOV, ORCID ID: 0000-0001-5694-632X Olga IAKUBCHAK, ORCID ID: 0000-0002-9390-6578 Ihor HRYSHCHUK, ORCID ID: 0000-0003-2571-6876 Liliana DAVYDOVSKA, ORCID ID: 0000-0003-5385-4500
12. Wang C, Yatsuya $\mathrm{H}$, Tamakoshi KH, Tamakoshi A. Milk drinking and mortality: findings from the Japan collaborative cohort study. Journal of epidemiology. 2015;25(1):66-73.

13. Hanuš O, Krížová L, Samková E, Špicka J, Kucera J, Klimešová M, Roubal $\mathrm{P}$, Jedelská R. The effectof cattle bread, season and type of diet on the fatty acid profile of raw milk. Arch. Anim. Breed. 2016;59:373-380.

14. Interstate standard GOST 52253-2004 Butter and butter paste from cow's milk. General technical conditions (with change №1). Valid, but does not operate in Ukraine. Міждержавний стандарт ГОСТ 52253-2004 (Масло и паста масляная из коровьего молока. Общие технические условия (с изменением №1) (Масло і паста масляна із коров'ячого молока. Загальні технічні умови (зі змінами №1)).

15. Yakubchak O, Taran T, Ushkalov V, Midyk S. Physicochemical and microbiological research of rawmilk material. Ukrainian Journal of Veterinary Sciences. 2021;12(2):26-37. doi:10.31548/ujvs 2021.02.003

16. Folch J, Leez M, Stanley G. A Simple Method for the Isolation and Purification of Total Lipides from Animal Tissues. Biol Chem. 1957;226(2):497-501.

17. DSTU ISO 5509-2002 Zhiri tvarinni i roslinni ta oliï. Prigotuvannja metilovih efiriv zhirnih kislot (Animal and vegetable fats and oils. Preparation of methyl esters of fatty acids) (ISO 5509:2000, IDT). 